\title{
EVALUATION OF THE RELATIONSHIP BETWEEN SUBCLINICAL HYPOTHYROIDISM AND METABOLIC SYNDROME COMPONENTS AMONG WORKERS
}

\section{MAUREEN JEPKORIR CHESEREK ${ }^{1,2,4}$, GUIRONG WU' ${ }^{2}$ LIYE SHEN $^{3}$, YONGHUI SHI ${ }^{1,2}$, and GUOWEI LE ${ }^{1,2}$}

\author{
${ }^{1}$ Jiangnan University, Wuxi, China
}

State Key Laboratory of Food Science and Technology

2 Jiangnan University, Wuxi, China

Molecular and Applied Nutrition Laboratory

${ }^{3}$ Jiangnan University, Wuxi, China

Jiangnan University Hospital

${ }^{4}$ Egerton University, Njoro, Kenya

Department of Human Nutrition

\begin{abstract}
Objectives: Both hyperthyroidism and overt hypothyroidism are associated with increased prevalence of metabolic syndrome and its components, while data on subclinical hypothyroidism is currently limited especially in working populations. The aim of this study was to examine the association between subclinical hypothyroidism and metabolic syndrome components in workers; and to evaluate whether there are differences by sex and occupation. Material and Methods: A total of 1150 university employees (male - 792, female - 358) aged 30-60 years who came for an annual medical check-up were studied. Anthropometric measurements were taken, and blood pressure, fasting plasma glucose (FPG), lipid profiles, thyroid stimulating hormone (TSH), free thyroxin (FT4) and free triiodothyronine (FT3) levels were measured. Results: After adjustment for age and body mass index (BMI), TSH was positively associated with increased triglyceride (TG) levels $(\beta=0.108, p=0.020)$ and FPG $(\beta=0.130, p=0.006)$ in subclinical hypothyroid male workers. However, TSH was not associated ( $p>0.05$ ) with any component of metabolic syndrome (MS) in the euthyroid group. In females, TSH was not correlated with MS components in both euthyroid and subclinical hypothyroid groups. Furthermore, comparison by occupation showed higher TSH in subclinical hypothyroid male workers employed in administration $(5.23 \pm 0.52 \mathrm{mU} / \mathrm{l})$ than those working as academics $(5.12 \pm 0.52 \mathrm{mU} / \mathrm{l})$, which resulted in elevated systolic and diastolic blood pressure, FPG, total cholesterol, TG and high density lipoprotein cholesterol. In females, BMI, systolic and diastolic blood pressure, TG and FPG were significantly $(\mathrm{p}<0.05)$ higher in subclinical hypothyroid administrators than those in academics. Conclusions: Subclinical hypothyroidism was associated with metabolic syndrome components in male workers and not in females. Administration workers showed increased metabolic risks compared to academics. The findings suggest that the assessment of thyroid function in individuals with metabolic syndrome in the workplace may be favorable especially among men.
\end{abstract}

Key words:

Cardiovascular risks, Metabolic syndrome, Occupation, Subclinical hypothyroidism, Thyroid hormones, University workers

Source of financial support: The project 212BAD33B05/metabolic syndrome and biomarkers. The National Science and Technology Ministry of China. Project manager: Guowei Le, Prof.

Received: November 14, 2013. Accepted: January 15, 2014

Corresponding author: G. Le, State Key Laboratory of Food Science and Technology, Jiangnan University, 1800 Lihu Road, Wuxi, 214122, Jiangsu Province, China (e-mail: lgw@jiangnan.edu.cn). 


\section{INTRODUCTION}

Metabolic syndrome (MS) is a cluster of risk factors including visceral obesity, hypertension, atherogenic dyslipidemia and hyperglycemia [1]. Although controversy still exists on its diagnostic relevance, MS is recognized as an independent risk factor for cardiovascular diseases (CVDs) and type 2 diabetes mellitus [2]. While it is known that its pathogenic mechanism is insulin resistance [3], accumulating research evidence indicates the importance of pancreatic $\beta$-cell defects and mass loss [4]. The MS is also associated with thyroid function due to the effects of thyroid hormones on lipids, glucose and blood pressure [5-7]. Importantly, alterations in lipids and other metabolic parameters are well recognized in patients with adverse thyroid disorders, mainly hyperthyroidism and overt hypothyroidism [8,9]. However, the association of MS with subclinical hypothyroidism (SCH), a mild thyroid disorder is inconsistently reported in many studies.

In some populations, $\mathrm{SCH}$ is shown to increase MS risks $[10,11]$, while in others $[12,13]$, it is reported to be associated with some components of MS, but not with MS as an entity. These conflicting results in studies may be ascribed to the influence of confounding factors such as age, gender and the body mass index. Moreover, some reports [14] indicate that thyroid stimulating hormone within normal reference ranges may also be related to MS and its components. SCH has recently attracted much attention due to its increased risks for coronary heart diseases and mortality [15]. Its high prevalence in many countries, including China, is ascribed to more than adequate intake of iodine [16] from long-term fortification of salt, high iodine levels in drinking water and consumption of sea foods. Currently, treatment of SCH with levothyroxine is recommended for some patients including pregnant women and patients with autoimmune thyroiditis [17].

In China, much attention is presently paid to prevention of CVDs and type 2 diabetes mellitus [18], and workplace can be an important environment for primary prevention.
Targeting MS may be an important approach [19]. However, there is little information on MS prevalence among workers as most reports are from the general population. Studies from other countries show high prevalence of MS among workers, and it is indicated to vary by age, gender and the occupation type [20]. The relationship of occupation and cardiovascular risks is related to the type of work and work environmental factors such as sedentary long time working works, overtime work, shift work and work stress [21,22]. Chronic stress has direct effects on hypothalamic-pituitary thyroid-adrenal axis and the sympathetic nervous system which results in clinical presentation of visceral obesity, type 2 diabetes, atherosclerosis and MS [23].

Importantly, thyroid hormones are end hormones of the hypothalamic-pituitary-thyroid axis that are altered in acute and repeated stress [24]. In China, despite the growing stress levels in university workers due heavy work load, long working hours and acute time pressure [25,26], there is paucity of data on the association of cardiovascular risks with thyroid function. Therefore, the objective of this study was to examine the association between $\mathrm{SCH}$ and MS components in university workers; and to evaluate whether there are differences by sex and occupation. Understanding the determinants of MS in the workplace may facilitate development of health interventions that aid in prevention, control and management of cardiovascular diseases and type 2 diabetes mellitus.

\section{MATERIAL AND METHODS}

\section{Participants and research design}

The participants were from a cross-sectional survey ( $\mathrm{N}=2428)$ of the project "212BAD33B05/metabolic syndrome and biomarkers", which was designed to evaluate the prevalence of metabolic syndrome and its components among university employees (unpublished work). These employees came for a routine annual medical check-up at 
the Jiangnan University Hospital. In the present study, we obtained a random sample of male $(\mathrm{N}=792)$ and female $(\mathrm{N}=358)$ adults (30-60 year old) for the evaluation of thyroid function. The employees were then categorized into 2 occupational groups: administration and academic workers. Administrators are involved with office work. They included the University top management staff, directors, deans of schools and their assistants, departmental heads, top management staff from human resources, student affairs, finance, procurement, as well as medical, library, security and housing department staff. Academic workers were involved with research and teaching, and they included professors, associate professors, lecturers and laboratory technicians.

Patients with diabetes, hyperthyroidism, sub-clinical hyperthyroidism, or individuals with history of thyroid disease or taking thyroxine or anti-thyroid drugs for treatment, or taking glucocorticosteroids, betablockers, amiodarone, antiepileptic drugs, salicylates, diuretics and other medications that affect thyroid function or taking lipid lowering drugs were excluded from the study. Also, pregnant women or those within the first year of the postpartum period were excluded from the study. An informed consent was given by all participants. Approval was obtained from the Jiangnan University Ethical Committee and University hospital management. Study protocols were conducted in accordance with the recommendations outlined in the Helsinki Declaration of 1975, as revised in 1983.

\section{Data collection}

Physical body assessment

Weight $(\mathrm{kg})$ and height $(\mathrm{m})$ were taken using a height and weight machine (HW-700, Zhengzhou, China) and used to compute the body mass index (BMI). Blood pressure was measured in the right arm using standard mercury sphygmomanometers (YE-665 A, Jiangsu, China) at a sitting position after $5 \mathrm{~min}$ of rest, and the mean systolic and diastolic blood pressure $(\mathrm{mm} \mathrm{Hg})$ of 2 measurements were recorded. All measurements were taken by trained health personnel.

\section{Biochemical analysis}

Overnight fasting blood samples were obtained in the morning between 8:00 a.m. and 11:00 a.m. and plasma was separated by centrifugation (KDC-1044, Hangzhou, China) at $1000 \times \mathrm{g}, 4^{\circ} \mathrm{C}$ for $10 \mathrm{~min}$. Immediately, plasma lipids and fasting plasma glucose were determined by enzymatic methods using an Automatic Biochemical Analyser (HF 400, Shanghai, China) at Jiangnan University hospital laboratory. Thyroid stimulating hormone (TSH), free thyroxine (FT4) and free triiodothyronine (FT3) were determined by radioimmunoassay (xh6080, Xi'an) at Beijing Sino-uk Institute of Biological Technology. The TSH assay sensitivity was $0.5 \mathrm{mU} / \mathrm{l}$, while the intra- and interassay coefficients of variations were $0.5 \%$ and $10 \%$, respectively. The FT3 assay sensitivity was $0.16 \mathrm{pmol} / \mathrm{l}$, whereas the intra- and inter-assay coefficients of variations were $5 \%$ and $9.8 \%$, respectively. The FT4 assay sensitivity was $0.15 \mathrm{pmol} / \mathrm{l}$, while the intra- and inter-assay coefficients of variations were $4.5 \%$ and $9.8 \%$, respectively.

\section{Definitions}

Metabolic syndrome

Metabolic syndrome was diagnosed based on the criteria contained in the Third Report of National Cholesterol Education Program Expert Panel on Detection, Evaluation, and Treatment of High Blood Cholesterol in Adults [27]. This criteria require the presence of at least 3 out of the following 5 components: waist circumference $\geq 90 \mathrm{~cm}$ (males), $\geq 80 \mathrm{~cm}$ (females); systolic blood pressure $\geq 130 \mathrm{~mm} \mathrm{Hg}$ or diastolic blood pressure $\geq 85 \mathrm{~mm} \mathrm{Hg}$ or subjects treated with antihypertensive drugs; fasting plasma glucose $(\mathrm{FPG}) \geq 5.6 \mathrm{mmol} / 1$; triglycerides $\geq 1.695 \mathrm{mmol} / \mathrm{l}$ and high density lipoprotein cholesterol $<1.036 \mathrm{mmol} / \mathrm{l}$ (males), $<1.295 \mathrm{mmol} / \mathrm{l}$ (females). 


\section{Thyroid function}

Thyroid function was assessed using TSH and thyroid hormone levels. Normal thyroid function (euthyroidism) was defined as TSH level of $0.40-4.5 \mathrm{mU} / 1$ with normal FT4 (9.19-25.60 pmol/l) and FT3 (3.20-9.20 pmol/l) levels. Subclinical hypothyroidism was defined as TSH levels of 4.5-10 mU/1 with normal FT4 and FT3 levels.

\section{STATISTICAL ANALYSIS}

The data were analyzed using a Statistical Package for Social Scientists for Windows, 18 (SPSS, Inc. Chicago, USA). They were presented as proportions and means \pm standard deviations. The t-test statistic was used to compare means for independent samples. The Chi-square $\left(\chi^{2}\right)$ test was used to compare categorical variables. Multiple linear regression analysis was performed to examine the relationship between TSH levels and FPG, plasma lipid parameters, systolic and diastolic blood pressure after adjusting for age and BMI. $P$ values $<0.05$ were considered statistically significant.

\section{RESULTS}

Table 1 shows the anthropometric and metabolic parameters of the male $(\mathrm{N}=792)$ and female $(\mathrm{N}=358)$ participants studied. The mean age was $46.9 \pm 7.6$ years. Male workers were older ( $46.5 \pm 7.7$ years) than the female ones ( $44.7 \pm 7$ years). The body mass index (BMI), lipid profiles (except total cholesterol - TC), systolic blood pressure (SBP), diastolic blood pressure (DBP), fasting plasma glucose (FPG) and thyroid hormone levels were also significantly higher $(p<0.01)$ in males compared to females, while high density lipoprotein cholester$\mathrm{ol}$ (HDL) was reduced. There was no difference $(\mathrm{p}>0.05)$ in the thyroid stimulating hormone (TSH) concentrations.

\section{Thyroid function and metabolic syndrome components}

Thyroid function of workers was evaluated to examine any possible association with lipids, glucose and blood pressure.
The TSH levels ranged between 3.201 and $6.949 \mathrm{mU} / \mathrm{l}$ while free thyroxine (FT4) and free triiodothyronine (FT3) were within normal reference levels of $<25.60 \mathrm{pmol} / \mathrm{l}$ and $<9.20 \mathrm{pmol} / \mathrm{l}$, respectively. Based on TSH and thyroid hormones levels, participants were categorized into 2 groups: euthyroidism and subclinical hypothyroidism (SCH).

Figure 1 shows an evaluation of the relationship between the thyroid status and the number of metabolic syndrome (MS) components. One MS component implies the presence of hypertension, hyperglycemia, and atherogenic dyslipidemia alone; 2 MS means the presence of 2 components, whereas $>3$ is the presence of 3 or more components. As shown below, there was a significant difference $\left(\chi^{2}=20.013\right.$, $\mathrm{p}=0.001)$ in the number of MS components in male adults with $\mathrm{SCH}$ as compared to those with normal thyroid function. The proportion of males with $2 \mathrm{MS}$ components was $24.5 \%$ and $9.1 \%$ in the SCH and euthyroid group, respectively. The corresponding proportions for the presence of 3 or more components were $9.5 \%$ and $2.9 \%$. In females, there was no significant difference $\left(\chi^{2}=3.604, p=0.307\right)$ in the number of components between the 2 thyroid groups. The comparison of metabolic parameters between the $2 \mathrm{TSH}$ groups is shown in Table 2. In males, the $\mathrm{SCH}$ group

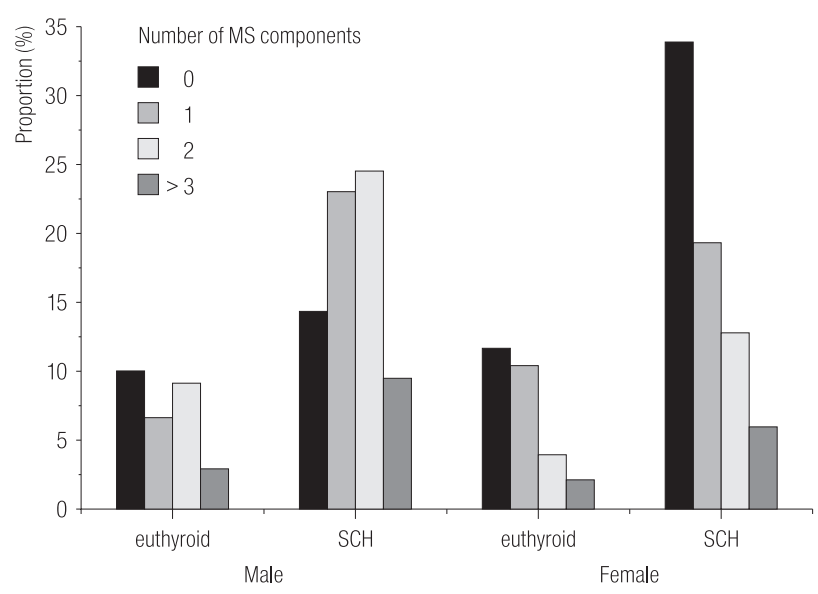

MS - metabolic syndrome; $\mathrm{SCH}$ - subclinical hypothyroidism. $\mathrm{p}<0.05$ significant by the $\mathrm{Chi}\left(\chi^{2}\right)$ test statistic.

Fig. 1. Prevalence of metabolic syndrome components by thyroid status 
Table 1. Anthropometric and metabolic parameters by sex

\begin{tabular}{lcccc}
\hline \multicolumn{1}{c}{ Parameters } & $\begin{array}{c}\text { Total } \\
(\mathrm{N}=1150)\end{array}$ & $\begin{array}{c}\text { Male } \\
(\mathrm{N}=792)\end{array}$ & $\begin{array}{c}\text { Female } \\
(\mathrm{N}=358)\end{array}$ & $\mathrm{p}$ \\
\hline Age (years) & $46.90 \pm 7.60$ & $46.50 \pm 7.70$ & $44.70 \pm 7.00$ & 0.001 \\
Weight $(\mathrm{kg})$ & $67.53 \pm 10.62$ & $71.63 \pm 9.18$ & $58.36 \pm 7.43$ & 0.001 \\
BMI $\left(\mathrm{kg} / \mathrm{m}^{2}\right)$ & $23.63 \pm 3.00$ & $24.26 \pm 2.90$ & $22.42 \pm 2.85$ & 0.001 \\
Systolic BP (mm Hg) & $125.87 \pm 15.26$ & $128.05 \pm 14.61$ & $121.07 \pm 15.59$ & 0.001 \\
Diastolic BP (mm Hg) & $85.04 \pm 9.68$ & $87.02 \pm 9.15$ & $80.64 \pm 9.41$ & 0.001 \\
Fasting plasma glucose (mmol/l) & $5.30 \pm 0.85$ & $5.39 \pm 0.92$ & $5.09 \pm 0.64$ & 0.001 \\
Total cholesterol (mmol/l) & $5.35 \pm 0.97$ & $5.37 \pm 0.97$ & $5.30 \pm 0.99$ & 0.255 \\
Triglycerides (mmol/l) & $1.589 \pm 0.964$ & $1.692 \pm 0.092$ & $1.363 \pm 0.861$ & 0.001 \\
LDL (mmol/l) & $2.89 \pm 0.82$ & $2.96 \pm 0.82$ & $2.78 \pm 0.80$ & 0.001 \\
HDL (mmol/l) & $1.442 \pm 0.378$ & $1.386 \pm 0.364$ & $1.564 \pm 0.381$ & 0.001 \\
TSH (mU/l) & $4.89 \pm 0.730$ & $4.87 \pm 0.72$ & $4.86 \pm 0.74$ & 0.754 \\
FT4 (pmol/l) & $18.58 \pm 2.52$ & $18.70 \pm 2.48$ & $18.30 \pm 2.58$ & 0.016 \\
FT3 (pmol/l) & $7.58 \pm 1.22$ & $7.72 \pm 1.27$ & $7.27 \pm 1.16$ & 0.001 \\
FT3/FT4 & $0.412 \pm 0.077$ & $0.417 \pm 0.078$ & $0.402 \pm 0.074$ & $0.009^{*}$ \\
\hline
\end{tabular}

Data are expressed as means \pm standard deviations.

BMI - body mass index; BP - blood pressure; LDL - low-density lipoprotein cholesterol; HDL - high-density lipoprotein cholesterol; TSH - thyroid stimulating hormone; FT3 - free triiodothyronine; FT4 - free thyroxine.

$\mathrm{p}<0.01$ significant by independent samples t-test.

${ }^{*} \mathrm{p}<0.05$.

Table 2. Comparison of metabolic parameters by thyroid status

\begin{tabular}{lcccccc}
\hline \multirow{2}{*}{ Parameters } & \multicolumn{7}{c}{ Male } & \multicolumn{3}{c}{ Female } \\
\cline { 2 - 6 } & $\begin{array}{c}\text { euthyroid } \\
(\mathrm{N}=260)\end{array}$ & $\begin{array}{c}\mathrm{SCH} \\
(\mathrm{N}=533)\end{array}$ & $\mathrm{p}^{*}$ & $\begin{array}{c}\text { euthyroid } \\
(\mathrm{N}=116)\end{array}$ & $\begin{array}{c}\text { SCH } \\
(\mathrm{N}=242)\end{array}$ & $\mathrm{p}^{*}$ \\
\hline Age $(\mathrm{years})^{\mathrm{a}}$ & $46.08 \pm 7.79$ & $46.72 \pm 7.70$ & 0.319 & $43.3 \pm 6.65$ & $44.5 \pm 8.8$ & 0.209 \\
$<35, \mathrm{n}(\%)^{\mathrm{b}}$ & $24(9.2)$ & $38(7.2)$ & - & $12(10.0)$ & $53(6.1)$ & - \\
$35-44, \mathrm{n}(\%)^{\mathrm{b}}$ & $83(31.9)$ & $147(27.6)$ & - & $46(40.0)$ & $213(35.1)$ & - \\
$45-54, \mathrm{n}(\%)^{\mathrm{b}}$ & $104(40.1)$ & $243(45.6)$ & - & $52(45.6)$ & $121(50.2)$ & - \\
$\geq 55, \mathrm{n}(\%)^{\mathrm{b}}$ & $49(18.8)$ & $105(19.6)$ & - & $6(4.4)$ & $21(8.7)$ & - \\
$\mathrm{BMI}\left(\mathrm{kg} / \mathrm{m}^{2}\right)^{\mathrm{a}}$ & $23.85 \pm 2.50$ & $24.53 \pm 2.83$ & 0.007 & $22.43 \pm 2.62$ & $22.45 \pm 3.002$ & 0.946 \\
$\mathrm{SBP}(\mathrm{mm} \mathrm{Hg})^{\mathrm{a}}$ & $125.86 \pm 12.99$ & $128.92 \pm 14.82$ & 0.009 & $121.8 \pm 14.5$ & $121.7 \pm 14.5$ & 0.957 \\
$\mathrm{DBP}(\mathrm{mm} \mathrm{Hg})^{\mathrm{a}}$ & $85.63 \pm 8.47$ & $87.56 \pm 9.17$ & 0.008 & $81.5 \pm 9.7$ & $80.67 \pm 9.09$ & 0.486 \\
$\mathrm{FPG}(\mathrm{mmol} /)^{\mathrm{a}}$ & $5.31 \pm 0.89$ & $5.46 \pm 0.91$ & 0.043 & $5.08 \pm 0.64$ & $5.08 \pm 0.54$ & 0.979 \\
$\mathrm{TC}(\mathrm{mmol} /)^{\mathrm{a}}$ & $5.26 \pm 0.97$ & $5.42 \pm 0.94$ & 0.041 & $5.20 \pm 0.86$ & $5.44 \pm 0.96$ & 0.039 \\
$\mathrm{TG}(\mathrm{mmol} /)^{\mathrm{a}}$ & $1.531 \pm 0.818$ & $1.738 \pm 0.972$ & 0.006 & $1.189 \pm 0.667$ & $1.371 \pm 0.660$ & 0.027 \\
$\mathrm{LDL}(\mathrm{mmol} /)^{\mathrm{a}}$ & $2.88 \pm 0.78$ & $3.02 \pm 0.74$ & 0.036 & $2.68 \pm 0.70$ & $2.880 \pm 0.776$ & 0.034 \\
$\mathrm{HDL}(\mathrm{mmol} / \mathrm{l})^{\mathrm{a}}$ & $1.383 \pm 0.343$ & $1.378 \pm 0.355$ & 0.844 & $1.575 \pm 0.389$ & $1.571 \pm 0.383$ & 0.933 \\
$\mathrm{TSH}(\mathrm{mU} / \mathrm{l})^{\mathrm{a}}$ & $4.05 \pm 0.31$ & $5.20 \pm 0.56$ & 0.001 & $4.02 \pm 0.33$ & $5.14 \pm 0.53$ & 0.001 \\
\hline
\end{tabular}


Table 2. Comparison of metabolic parameters by thyroid status - cont.

\begin{tabular}{|c|c|c|c|c|c|c|}
\hline \multirow[b]{2}{*}{ Parameters } & \multicolumn{3}{|c|}{ Male } & \multicolumn{3}{|c|}{ Female } \\
\hline & $\begin{array}{l}\text { euthyroid } \\
(\mathrm{N}=260)\end{array}$ & $\begin{array}{c}\mathrm{SCH} \\
(\mathrm{N}=533)\end{array}$ & $\mathrm{p}^{*}$ & $\begin{array}{l}\text { euthyroid } \\
(\mathrm{N}=116)\end{array}$ & $\begin{array}{c}\text { SCH } \\
(\mathrm{N}=242)\end{array}$ & $\mathrm{p}^{*}$ \\
\hline FT4 $(\mathrm{pmol} / 1)^{\mathrm{a}}$ & $18.43 \pm 2.47$ & $18.75 \pm 2.45$ & 0.899 & $18.14 \pm 2.31$ & $18.28 \pm 2.40$ & 0.645 \\
\hline FT3 $(\mathrm{pmol} / 1)^{\mathrm{a}}$ & $7.76 \pm 1.27$ & $7.73 \pm 1.20$ & 0.770 & $7.35 \pm 0.85$ & $7.29 \pm 0.96$ & 0.658 \\
\hline FT3/FT4 & $0.417 \pm 0.078$ & $0.416 \pm 0.078$ & 0.915 & $0.409 \pm 0.065$ & $0.398 \pm 0.059$ & 0.212 \\
\hline
\end{tabular}

${ }^{a}$ Data are expressed as means \pm standard deviations.

${ }^{b}$ Analysis by the Chi-square $\left(\chi^{2}\right)$ test: males $\left(\chi^{2}=2.782, p=0.300\right)$; females $\left(\chi^{2}=3.661, p=0.300\right)$.

$\mathrm{SCH}$ - subclinical hypothyroidism; DBP - diastolic blood pressure; FPG - fasting plasma glucose; TC - total cholesterol.

$* \mathrm{p}<0.05$ significant by independent samples t-test.

Other abbreviations as in Table 1.

showed significantly $(\mathrm{p}<0.05$ ) elevated BMI, SBP, DBP, FPG, TC, triglycerides (TG) and low density lipoprotein cholesterol (LDL), however, no difference was found in age and HDL. In females, only TC, TG and LDL were increased, while age, BMI, SBP, DBP, FPG and HDL were not different between the 2 groups. As expected, the TSH levels were higher $(\mathrm{p}<0.001)$ in the SCH group than in the euthyroid group, while the thyroid hormone levels were similar.

Table 3 shows the multiple linear regression models of the association between TSH and metabolic parameters in both the euthyroid and the subclinical hypothyroid group. In both sexes, there was no association ( $p>0.05)$ between TSH and all the parameters in the euthyroid group. In the SCH group, after adjustment for age and BMI, TSH was positively correlated with $\mathrm{TG}(\beta=0.108, \mathrm{p}=0.020)$ and $\mathrm{FPG}(\beta=0.130$, $\mathrm{p}=0.006)$ in male workers, while no such correlation was found in females. TSH was not correlated with SBP, diastolic blood pressure (DBP), TC, LDL and HDL.

\section{Occupation and subclinical hypothyroidism}

To evaluate any possible differences in cardiovascular risks between occupation types, a comparison of metabolic parameters was examined between subclinical hypothyroid workers employed in administration and those employed as academics. As demonstrated in Table 4, male workers in administration showed increased SBP, DBP, FPG, TC, TG and HDL as compared to, academics while no differences were not found as for age, BMI and LDL. In females, BMI, SBP, DBP, FPG and TG were higher in the administration staff as compared to academics, while

Table 3. Association between thyroid stimulating hormone and metabolic risk factors in euthyroidism and subclinical hypothyroidism

\begin{tabular}{|c|c|c|c|c|c|c|c|c|}
\hline \multirow{3}{*}{ Parameters } & \multicolumn{4}{|c|}{ Male } & \multicolumn{4}{|c|}{ Female } \\
\hline & \multicolumn{2}{|c|}{$\begin{array}{l}\text { euthyroid } \\
(\mathrm{N}=260)\end{array}$} & \multicolumn{2}{|c|}{$\begin{array}{c}\text { SCH } \\
(\mathrm{N}=533)\end{array}$} & \multicolumn{2}{|c|}{$\begin{array}{l}\text { euthyroid } \\
(\mathrm{N}=116)\end{array}$} & \multicolumn{2}{|c|}{$\begin{array}{c}\text { SCH } \\
(\mathrm{N}=242)\end{array}$} \\
\hline & $\beta$ & $\mathrm{p}$ & $\beta$ & $\mathrm{p}$ & $\beta$ & $\mathrm{p}$ & $\beta$ & $\mathrm{p}$ \\
\hline \multicolumn{9}{|l|}{$\mathrm{SBP}(\mathrm{mm} \mathrm{Hg})$} \\
\hline model 1 & -0.039 & 0.563 & -0.040 & 0.362 & -0.113 & 0.285 & -0.047 & 0.489 \\
\hline model 2 & 0.049 & 0.508 & -0.040 & 0.388 & -0.154 & 0.159 & -0.113 & 0.123 \\
\hline \multicolumn{9}{|c|}{ DBP (mm Hg) } \\
\hline model 1 & -0.041 & 0.546 & -0.062 & 0.163 & -0.114 & 0.276 & 0.022 & 0.743 \\
\hline model 2 & 0.059 & 0.418 & -0.066 & 0.162 & -0.126 & 0.254 & -0.060 & 0.400 \\
\hline
\end{tabular}


Table 3. Association between thyroid stimulating hormone and metabolic risk factors in euthyroidism and subclinical hypothyroidism - cont.

\begin{tabular}{|c|c|c|c|c|c|c|c|c|}
\hline \multirow{3}{*}{ Parameters } & \multicolumn{4}{|c|}{ Male } & \multicolumn{4}{|c|}{ Female } \\
\hline & \multicolumn{2}{|c|}{$\begin{array}{l}\text { euthyroid } \\
(\mathrm{N}=260)\end{array}$} & \multicolumn{2}{|c|}{$\begin{array}{c}\mathrm{SCH} \\
(\mathrm{N}=533)\end{array}$} & \multicolumn{2}{|c|}{$\begin{array}{l}\text { euthyroid } \\
(\mathrm{N}=116)\end{array}$} & \multicolumn{2}{|c|}{$\begin{array}{c}\text { SCH } \\
(\mathrm{N}=242)\end{array}$} \\
\hline & $\beta$ & $\mathrm{p}$ & $\beta$ & $p$ & $\beta$ & $\mathrm{p}$ & $\beta$ & $\mathrm{p}$ \\
\hline \multicolumn{9}{|l|}{ FPG (mmol/l) } \\
\hline model 1 & 0.879 & 0.879 & 0.123 & $0.005^{*}$ & -0.192 & 0.100 & 0.054 & 0.428 \\
\hline model 2 & 0.285 & 0.285 & 0.130 & $0.006^{*}$ & -0.178 & 0.131 & 0.076 & 0.304 \\
\hline \multicolumn{9}{|l|}{ TC (mmol/l) } \\
\hline model 1 & -0.040 & 0.573 & 0.019 & 0.671 & 0.143 & 0.196 & 0.110 & 0.108 \\
\hline model 2 & 0.029 & 0.714 & 0.043 & 0.370 & 0.135 & 0.249 & 0.088 & 0.241 \\
\hline \multicolumn{9}{|l|}{ TG (mmol/l) } \\
\hline model 1 & -0.037 & 0.600 & 0.121 & $0.006 *$ & 0.094 & 0.396 & 0.118 & 0.095 \\
\hline model 2 & 0.006 & 0.940 & 0.108 & $0.020^{*}$ & 0.083 & 0.474 & 0.054 & 0.483 \\
\hline \multicolumn{9}{|l|}{$\mathrm{LDL}(\mathrm{mmol} / \mathrm{l})$} \\
\hline model 1 & -0.042 & 0.553 & -0.008 & 0.856 & 0.219 & 0.118 & 0.072 & 0.179 \\
\hline model 2 & 0.026 & 0.734 & 0.014 & 0.778 & 0.098 & 0.403 & 0.050 & 0.289 \\
\hline \multicolumn{9}{|c|}{$\mathrm{HDL}(\mathrm{mmol} / \mathrm{l})$} \\
\hline model 1 & -0.053 & 0.450 & -0.046 & 0.296 & 0.002 & 0.988 & -0.037 & 0.590 \\
\hline model 2 & -0.086 & 0.271 & -0.054 & 0.250 & 0.037 & 0.741 & -0.013 & 0.863 \\
\hline
\end{tabular}

Other abbreviations as in Table 1 and 2.

$* \mathrm{p}<0.05$ significant by multiple linear regression.

Values of $\beta$ are standardized regression coefficients; model 1, after adjustment for age; model 2, further adjustment for body mass index.

Table 4. Comparison of metabolic parameters of subclinical hypothyroid male and female workers by occupation

\begin{tabular}{lcccccc}
\hline \multirow{2}{*}{ Parameters } & \multicolumn{3}{c}{ Male } & \multicolumn{3}{c}{ Female } \\
\cline { 2 - 6 } & $\begin{array}{c}\text { academic } \\
(\mathrm{N}=314)\end{array}$ & $\begin{array}{c}\text { administration } \\
(\mathrm{N}=219)\end{array}$ & $\mathrm{p}$ & $\begin{array}{c}\text { academic } \\
(\mathrm{N}=130)\end{array}$ & $\begin{array}{c}\text { administration } \\
(\mathrm{N}=112)\end{array}$ & $\mathrm{p}$ \\
\hline Age (years) & $47.90 \pm 5.90$ & $48.70 \pm 7.30$ & 0.200 & $45.40 \pm 6.90$ & $45.40 \pm 6.10$ & 0.977 \\
BMI $\left(\mathrm{kg} / \mathrm{m}^{2}\right)$ & $24.24 \pm 2.30$ & $24.36 \pm 2.51$ & 0.569 & $22.12 \pm 3.19$ & $23.23 \pm 2.43$ & $0.019^{*}$ \\
SBP $(\mathrm{mm} \mathrm{Hg})$ & $126.86 \pm 15.63$ & $131.89 \pm 14.61$ & $0.001^{* *}$ & $119.65 \pm 13.73$ & $125.80 \pm 15.24$ & $0.002^{*}$ \\
DBP $(\mathrm{mm} \mathrm{Hg})$ & $86.43 \pm 9.30$ & $89.18 \pm 8.75$ & $0.001^{* *}$ & $79.21 \pm 8.80$ & $83.75 \pm 8.98$ & $0.001^{* *}$ \\
FPG (mmol/l) & $5.31 \pm 0.80$ & $5.57 \pm 0.86$ & $0.001^{*}$ & $5.01 \pm 0.47$ & $5.18 \pm 0.50$ & $0.012^{*}$ \\
TC $(\mathrm{mmol} / \mathrm{l})$ & $5.33 \pm 0.92$ & $5.50 \pm 0.91$ & $0.034^{*}$ & $5.40 \pm 0.88$ & $5.30 \pm 0.65$ & 0.383 \\
TG (mmol/l) & $1.644 \pm 0.771$ & $1.813 \pm 0.987$ & $0.029^{*}$ & $1.436 \pm 0.654$ & $1.194 \pm 0.518$ & $0.006^{*}$ \\
LDL (mmol/l) & $3.00 \pm 0.76$ & $3.03 \pm 0.72$ & 0.686 & $2.92 \pm 0.81$ & $2.80 \pm 0.68$ & 0.305 \\
HDL $(\mathrm{mmol} / \mathrm{l})$ & $1.344 \pm 0.343$ & $1.425 \pm 0.366$ & $0.009^{*}$ & $1.558 \pm 0.390$ & $1.559 \pm 0.338$ & 0.440 \\
\hline
\end{tabular}

Data are expressed as means \pm standard deviations.

$* * \mathrm{p}<0.01$.

$* \mathrm{p}<0.05$ significant by independent samples t-test.

Abbreviations as in Table 1 and 2. 
Table 5. Comparison of thyroid stimulating hormone and thyroid hormone levels of subclinical hypothyroid male and female workers by occupation

\begin{tabular}{lrccccc}
\hline \multirow{2}{*}{ Parameters } & \multicolumn{3}{c}{ Male } & \multicolumn{3}{c}{ Female } \\
\cline { 2 - 7 } & $\begin{array}{r}\text { academic } \\
(\mathrm{N}=314)\end{array}$ & $\begin{array}{c}\text { administration } \\
(\mathrm{N}=219)\end{array}$ & $\mathrm{p}$ & $\begin{array}{c}\text { academic } \\
(\mathrm{N}=130)\end{array}$ & $\begin{array}{c}\text { administration } \\
(\mathrm{N}=112)\end{array}$ & $\mathrm{p}$ \\
\hline TSH $(\mathrm{mU} / \mathrm{l})$ & $5.12 \pm 0.52$ & $5.23 \pm 0.52$ & 0.024 & $5.07 \pm 0.48$ & $5.23 \pm 0.57$ & 0.029 \\
FT4 (pmol/l) & $18.57 \pm 2.46$ & $19.02 \pm 2.40$ & 0.041 & $18.09 \pm 2.40$ & $18.85 \pm 2.52$ & 0.026 \\
FT3 (pmol/l) & $7.73 \pm 1.23$ & $7.71 \pm 1.16$ & 0.857 & $7.17 \pm 1.23$ & $7.19 \pm 1.18$ & 0.915 \\
FT3/FT4 & $0.42 \pm 0.07$ & $0.41 \pm 0.07$ & 0.093 & $0.39 \pm 0.069$ & $0.39 \pm 0.07$ & 0.485 \\
\hline
\end{tabular}

Data are expressed as means \pm standard deviations.

Abbreviations as in Table 1.

$\mathrm{p}<0.05$ significant by independent samples t-test.

no difference $(\mathrm{p}>0.05)$ was found as for age, TC, HDL and LDL. Furthermore, an evaluation of TSH and thyroid hormone levels showed a marked difference between the 2 occupation groups (Table 5). In both males and females, TSH and FT4 levels were significantly $(\mathrm{p}<0.05)$ higher in administrative workers as compared to academics, while FT3 and FT3/FT4 levels remained unchanged.

\section{DISCUSSION}

The study showed marked heterogeneity in metabolic alterations by gender, occupation and thyroid function. In the study, a dyslipidemic pattern, increased blood pressure, and, hyperglycemia were observed in male workers compared to females (Table 1). This is attributed to the action of thyroid hormone, triiodothyronine (T3) on lipids, carbohydrates and on the cardiovascular system. Notably, free thyroxine (FT4) and FT3 levels were significantly higher in males than females despite similar levels of thyroid stimulating hormone (TSH). It is possible that TSH stimulated increased production of $\mathrm{T} 4$, which in turn was activated to T3 since the FT3/FT4 ratio was also increased in males. T3 affects the synthesis, mobilization and degradation of lipids, although degradation is influenced more than synthesis [5]. Thus, increased levels stimulate fat mobilization, leading to elevated concentrations of fatty acids in the plasma. T3 can also stimulate hepatic glucose production via direct effect on the liver or indirectly via a sympathetic pathway from the hypothalamus [6]. The T3 mediated effects on the systemic vasculature include relaxation of vascular smooth muscle resulting in decreased arterial resistance and diastolic blood pressure [7]. Thus, in hyperthyroidism, cardiac contractility and cardiac output are enhanced and systemic vascular resistance is decreased, while in hypothyroidism, the opposite outcome is observed.

Gender disparity in cardiovascular risks is ascribed to sex-differences in lipid metabolism and lipoprotein kinetics [28]. The sex hormone, estrogen, is known to have protective effect against atherogenicity in premenopausal women, while low testosterone levels in males are positively associated with metabolic syndrome (MS) [29]. This is usually mediated by obesity and insulin resistance. Differences may also be due to the sex-specific changes in adiposity patterns that cause differential secretion of adipocyte hormones and inflammatory markers known to increase cardiovascular risks [30]. Generally, women tend to develop more subcutaneous adipose tissue, whereas men are prone to visceral adipose tissue. Moreover, cardiovascular risk factors such as cigarette smoking and alcohol consumption are known to be more common in Chinese men than women [31,32]. 
Furthermore, gender disparity was observed as regards the effect of thyroid hormones on MS components. Male workers with subclinical hypothyroidism $(\mathrm{SCH})$ were found to be more prone to clustering of metabolic risks than those with normal thyroid function (Figure 1), while such differences were not observed in females. As mentioned earlier, this could be due to increased production of T3, which in turn affected lipids, glucose and blood pressure. Moreover, a comparison of metabolic parameters between the $2 \mathrm{TSH}$ levels indicated an increase in BMI, blood pressure, glucose, and atherogenic lipids in males with $\mathrm{SCH}$ as compared to euthyroids, while only atherogenic lipids were altered in females (Table 2). This is attributed to high body weight, which is known to influence TSH production via recognized mechanisms such as the adipocyte hormone, namely leptin that affects the conversion of $\mathrm{T} 4$ to $\mathrm{T} 3$.

Further adjustments for age and BMI showed a positive association of TSH with TG and FPG in male workers with $\mathrm{SCH}$, and interestingly, no such association was found in females (Table 3). This finding indicates that TSH independently induced hypertryglyceridemia and hyperglycemia in male workers, since thyroid hormone levels were similar in both the euthyroid and SCH group. Moreover, TSH, either within normal or within mildly elevated levels, did not affect blood pressure and HDL in both sexes. So far, most studies have shown controversial results with regard to the relationship of mildly elevated TSH with blood pressure and HDL levels. In addition, the finding that SCH was not associated with any cardiovascular risks in women concurs with a similar study of women in a workplace [33]. Thus, there is a possibility that a mild elevation of TSH may not result in cardiovascular risks in middle-aged women as compared to men of the same age.

Metabolic alterations are recognized in hyperthyroidism and in individuals with TSH > $10 \mathrm{mUl}[8,9]$ however reports on $\mathrm{SCH}$ show inconsistent results in some populations [10,11]. Similarly to this study, Liu et al. [12] and Tehrani et al. [13] reported that $\mathrm{SCH}$ is associated with some components only and not all of them [12,13]. In contrast, some studies demonstrate that MS and its components are present in individuals with normal TSH and thyroid hormones levels, and that TSH within normal ranges could alter lipid levels independently of thyroid hormones [14]. In the current study however, TSH was not associated with any metabolic risks in both sexes in the euthyroid group. These inconsistencies could be related to the age of participants or different sample sizes.

The molecular mechanism for metabolic alterations in $\mathrm{SCH}$ is related to the activation of genes of key enzymes involved in lipid and glucose metabolism by T3 [34]. T3 up-regulates LDL receptors by controlling the LDL gene receptor via binding to specific thyroid hormone responsive elements in the promoter regions of a positively regulated gene [35]. It also controls the sterol regulatory element-binding protein, which regulates LDL receptor's gene expression. Thus, in the study, hypercholesterolemia was due to decreased fractional clearance of LDL in the liver as a result of reduced number of LDL receptors, while reduced activity of lipoprotein lipase led to high TG levels. In addition, hyperglycemia may be attributed to increased glucose- 6 phosphatase and glucose transporter GLUT 2 mRNA expression, or decreased mRNA expression of protein kinase B [36], while changes in blood pressure may have resulted from increased peripheral vascular resistance or abnormality in sodium metabolism.

The study also showed that metabolic parameters in $\mathrm{SCH}$ differed by occupation type. The type of work was shown to influence MS prevalence in certain occupations [20-22]. However, most of these studies focused on the effect of heavy manual work, night shifts or long working hours, while few evaluated cardiovascular risks in relation to the form of work (sitting or standing etc.). Although many studies have attempted to explain the mechanisms for occupational difference in cardiovascular risks, there is 
lack of data on the impact of occupation and thyroid hormones on MS prevalence.

In this study, a varied clustering of cardiovascular risks was observed between administration workers and academics. It was found that the subclinical hypothyroid male workers in administration showed increased blood pressure, hyperglycemia and dyslipidemia as compared to academics (Table 4). The corresponding increase in TSH levels (Table 5) in administrators suggests that elevated TSH caused the differences in metabolic risks between the 2 occupations. It was also observed that female administrators had elevated blood pressure, FPG and TG compared to academic staff. Unlike in the case of the male subjects, this difference is attributable to increased body weight. In males, there was no difference in BMI between the 2 occupation groups.

Although not evaluated in the current study, work stress could possibly have altered thyroid hormone levels causing hypothyroidism [24]. This happens due to the activation of the hypothalamic-pituitary adrenal axis and the sympathetic nervous system, which results in increased cortisol and catecholamines, respectively [23], contributing to insulin resistance and visceral fat accumulation. Visceral fat accumulation in turn leads to increased circulation of circulatory adipokines, and consequently MS. Thus, in the context of the present study, managing people and resources may be more stressful than teaching at universities. Importantly, empirical studies in China report increased work stress in university workers [26]. This work stress at universities is shown to be influenced by gender and position [25]. In the workplace examined in the current study, most senior positions with greater responsibilities are held by males. Thus, they may have been exposed to much more work-related stress as compared to women. Noteworthy, long working hours, overtime and extended work schedules are common phenomena at Chinese universities and could result in burnout, a major mediator of job stress and poor health [37].
Occupational differences in metabolic risks could also be due to the form of work. Administrators are usually more confined to their offices during working hours, since their work involves management of personnel and resources, as compared to academic workers. Thus, they spend several consecutive hours sitting down on a regular basis. Physical activity can influence the hypothalamic-pituitary-thyroid axis. Ravaglia et al. [38] demonstrated that physically active men had lower TSH levels as compared to sedentary men. Among Chinese adults, Du et al. [39] showed that physical activity varied substantially by occupations and that lack of physical activity and excess sedentary leisure time, independently and jointly, was associated with greater adiposity.

Too much uninterrupted sitting results in very low energy expenditure which increases cardiometabolic risks [40]. A meta-analysis of ten cross-sectional studies reported increased odds for MS by $73 \%$ in people who spend higher amounts of time on sedentary behaviors [41]. The authors suggested that sedentary time could be an independent determinant of metabolic dysfunction distinct to that of physical inactivity. Among other mechanisms, this could be attributed to reduction in muscle lipoprotein lipase activity and a consequent decline in the uptake of triglycerides and a decrease in HDL cholesterol [42]. Other possible reasons could be related to lifestyle factors including dietary habits, alcohol consumption and cigarette smoking. However, differences between the 2 occupations in this workplace may be insignificant as participants obtain their main meals from university cafeteria and restaurants that offer similar foods. Likewise, differences in smoking and alcohol consumption may be slight as these risk factors are known social-cultural aspects among the Chinese $[43,44]$ and thus may not vary between the 2 occupational groups. One limitation of the study is the crosssectional nature of the design, which does not allow for determining the cause-effect relationship. The findings indicate associations between moderately elevated thyroid 
stimulating hormone levels with metabolic risks and may not indicate causal links. Thus, prospective studies are needed to determine the significance of early detection of subclinical hypothyroidism and longer-term associations with metabolic syndrome.

\section{CONCLUSION}

The study demonstrated that subclinical hypothyroidism was associated with metabolic syndrome components in male workers and not in females. It was also shown that administration workers had increased cardiovascular risks as compared to academic staff. Thus, assessment of thyroid function in individuals with metabolic syndrome components in the workplace may be favorable especially among men. The findings may also aid in developing gender- and occupation-specific workplace interventions for the prevention of cardiovascular diseases and type 2 diabetes.

\section{REFERENCES}

1. Leroith D. Pathophysiology of the metabolic syndrome: implications for the cardiometabolic risks associated with type 2 diabetes. Am J Med Sci. 2012;343(1):13-6, http:// dx.doi.org/10.1097/MAJ.0b013e31823ea214.

2. Wilson PW, D'Agostino RB, Parise H, Sullivan L, Meigs JB. Metabolic syndrome as a precursor of cardiovascular disease and type 2 diabetes mellitus. Circulation. 2005;112(20):3066-72, http://dx.doi.org/10.1161/CIRCULATIONAHA.105.539528.

3. Gallagher EJ, Leroith D, Karnieli E. Insulin resistance in obesity as the underlying cause for the metabolic syndrome. Mt Sinai J Med. 2010;77(5):511-23, http://dx.doi.org/10.1002/ msj.20212.

4. Meier JJ, Bonadonna RC. Role of reduced $\beta$-cell mass versus impaired $\beta$-cell function in the pathogenesis of type 2 diabetes. Diabetes Care. 2013;36(Suppl 2):S113-9, http://dx.doi. org $/ 10.2337 / \mathrm{dcS} 13-2008$.
5. Pucci E, Chiovato L, Pinchera A. Thyroid and lipid metabolism. Int J Obes Relat Metab Disord. 2000;24(Suppl 2):S109-12, http://dx.doi.org/10.1038/sj.ijo.0801292.

6. Klieverik LP, Janssen SF, van Riel A, Foppen E, Bisschop PH, Serlie MJ, et al. Thyroid hormone modulates glucose production via a sympathetic pathway from the hypothalamic paraventricular nucleus to the liver Proc Natl Acad Sci USA. 2009;106(14):5966-71, http://dx.doi.org/10.1073/pnas. 0805355106.

7. Danzi S, Klein I. Thyroid hormone and the cardiovascular system. Minerva Endocrinol. 2004;29(3):139-50.

8. Collet TH, Gussekloo J, Bauer DC, den Elzen WP, Cappola AR, Balmer P, et al. Subclinical hyperthyroidism and the risk of coronary heart disease and mortality. Arch Intern Med. 2012;172(10):799-809, http://dx.doi.org/10.1001/ archinternmed.2012.402.

9. Peppa M, Betsi G, Dimitriadis G. Lipid abnormalities and cardiometabolic risk in patients with overt and subclinical thyroid disease. J Lipids. 2011;575840:1-9, http://dx.doi. org/10.1155/2011/575840.

10. Lai Y, Wang J, Jiang F, Wang B, Chen Y, Li M, et al. The relationship between serum thyrotropin and components of metabolic syndrome. Endocrine J. 2011;58(1):23-30, http:// dx.doi.org/10.1507/endocrj.K10E-272.

11. Meher LK, Raveendranathan SK, Kota SK, Sarangi J, Jali SN. Prevalence of hypothyroidism in patients with metabolic syndrome. Thyroid Res Pract. 2013;10(2):60-4.

12. Liu C, Scherbaum WA, Schott M, Schinner S. Subclinical hypothyroidism and the prevalence of the metabolic syndrome. Horm Metab Res. 2011;43(6):417-21, http://dx.doi. org/10.1055/s-0031-1275719.

13. Tehrani FR, Tohidi M, Dovom MR, Azizi F. A population based study on the association of thyroid status with components of the metabolic syndrome. J Diabetes Metab. 2011;2:8, http://dx.doi.org/10.4172/2155-6156.1000156.

14. Wang F, Tan Y, Wang C, Zhang X, Zhao Y, Song X, et al. Thyroid-stimulating hormone levels within the reference range are associated with serum lipid profiles independent 
of thyroid hormones. J Clin Endocrinol Metab. 2012;97(8):2724-31, http://dx.doi.org/10.1210/jc.2012-1133.

15. Rodondi N, den Elsen WP, Bauer DC, Cappola AR, Razvi S, Walsh JP, et al. Subclinical hypothyroidism and the risk of coronary heart disease and mortality. JAMA. 2010;304(12): 1365-74, http://dx.doi.org/10.1001/jama.2010.1361.

16. Teng X, Shan Z, Chen Y, Lai Y, Yu J, Shan L, et al. More than adequate iodine intake may increase subclinical hypothyroidism and autoimmune thyroiditis: A cross-sectional study based on two Chinese communities with different iodine intake levels. Eur J Endocrinol. 2011:164:943-50, http:// dx.doi.org/10.1530/EJE-10-1041.

17. Garber JR, Cobin RH, Gharib H, Hennessey JV, Klein I, Mechanick JI, et al. Clinical practice guidelines for hypothyroidism in adults: Cosponsored by the American Association of Clinical Endocrinologists and the American Thyroid Association. Thyroid. 2012,22(12): 1200-35, http://dx.doi. org/10.1089/thy.2012.0205.

18. Yang ZJ, Liu J, Ge JP, Chen L, Zhao ZG, Yang WY. Prevalence of cardiovascular disease risk factor in the Chinese population: The 2007-2008 China National Diabetes and Metabolic Disorders Study. Eur Heart J. 2012;33(2):213-20, http://dx.doi.org/10.1093/eurheartj/ehr205.

19. Dunkley J, Charles K, Gray LJ, Camosso-Stefinovic J, Davies MJ, Khunti K. Effectiveness of interventions for reducing diabetes and cardiovascular disease risk in people with metabolic syndrome: systematic review and mixed treatment comparison meta-analysis. Diabetes Obes Metab. 2012;14(7): 616-25, http://dx.doi.org/10.1111/j.1463-1326.2012.01571.x.

20. Wang XS, Armstrong MEG, Cairns BJ, Key TJ, Travis RC. Shift work and chronic disease: The epidemiological evidence. Occup Med. 2011;61:78-89, http://dx.doi.org/10.1093/ occmed/kqr001.

21. Mohebbi I, Shateri K, Seyedmohammadzad M. The relationship between working schedule patterns and the markers of the metabolic syndrome: Comparison of shift workers with day workers. Int J Occup Med Environ Health. 2012;25(4): 383-9, http://dx.doi.org/10.2478/S13382-012-0051-51.
22. Myong JP, Kim HR, Kyunghee JC, Baker D, Choi BK. Disparities of metabolic syndrome prevalence by age, gender and occupation among Korean adult workers. Ind Health. 2012;50:115-22, http://dx.doi.org/10.2486/indhealth. MS1328.

23. Cagampang FR, Poore KR, Hanson MA. Developmental origins of the metabolic syndrome: Body clocks and stress responses. Brain Behav Immun. 2011;25:214-20, http:// dx.doi.org/10.1016/j.bbi.2010.09.005.

24. Ranabir S, Reetu K. Stress and hormones. Indian J Endocrinol Metab. 2011;15(1):18-22, http://dx.doi.org/10.4103/22308210.77573.

25. Slišković A, Maslić-Seršić D. Work stress among university teachers: gender and position differences. Arh Hig Rada Toksikol. 2011;62:299-307, http://dx.doi.org/10.2478/100041254-62-2011-2135.

26. Sun W, Hu H, Wang L. Occupational stress and its related factors among university teachers in China. J Occup Health. 2011;53:280-6, http://dx.doi.org/10.1539/joh.100058-OA.

27. Expert Panel on Detection, Evaluation, and Treatment of High Blood Cholesterol in Adults. Executive summary of the Third Report of the National Cholesterol Education Program (NCEP) Expert Panel on Detection, Evaluation, and Treatment of High Blood Cholesterol in Adults (Adult Treatment Panel III). JAMA. 2001;285:2486-97, http:// dx.doi.org/10.1001/jama.285.19.2486.

28. Wang X, Magkos F, Mittendorfer B. Sex differences in lipid and lipoprotein metabolism: it's not just about sex hormones. J Clin Endocrinol Metab. 2011;96(4):885-93, http:// dx.doi.org/10.1210/jc.2010-2061.

29. Kweon SS, Shin MH, Nam HS, Jeong SK, Park KS, Choi JS, et al. Sex differences in the associations of testosterone and sex hormone-binding globulin with metabolic syndrome in middle-aged and elderly Koreans - The Namwon Study. Circ J. 2013;77:734-40, http://dx.doi.org/10.1253/circj.CJ-12-0613.

30. Liu J, Fox CS, Hickson DA, May WD, Hairston KG, Carr JJ, et al. Impact of abdominal visceral and subcutaneous 
adipose tissue on cardiometabolic risk factors: The Jackson heart study. Clin Endocrinol Metab. 2010;95(12):5419-26, http://dx.doi.org/10.1210/jc.2010-1378.

31. Zhu Y, Zhang M, Hou X, Lu J, Peng L, Gu H, et al. Cigarette smoking increases risk for incident metabolic syndrome in Chinese men-Shanghai diabetes study. Biomed Environ Sci. 2011;24(5):475-82.

32. Jin L, Huang Y, Bi Y, Zhao L, Xu M, Xu Y, et al. Association between alcohol consumption and metabolic syndrome in 19,215 middle-aged and elderly Chinese. Diabetes Res Clin Pract. 2011;92(3):386-92, http://dx.doi.org/10.1016/ j.diabres.2011.02.033.

33. Diaz-Olmos R, Nogueira AC, Penalva DQ, Lotufo PA, Benseñor IM. Frequency of subclinical thyroid dysfunction and risk factors for cardiovascular disease among women at a workplace. Sao Paulo Med J. 2010;128(1):18-23, http://dx.doi.org/10.1590/S1516-31802010000100005.

34. Rizos CV, Elisaf MS, Liberopoulos EN. Effects of thyroid dysfunction on lipid profile. Open Cardiovasc Med J. 2011;5: 76-84, http://dx.doi.org/10.2174/1874192401105010076.

35. Duntas LH, Brenta G. The effect of thyroid disorders on lipid levels and metabolism. Med Clin North Am. 2012;96(2): 269-81, http://dx.doi.org/10.1016/j.mcna.2012.01.012.

36. Brenda G. Why can insulin resistance be a natural consequence of thyroid dysfunction? J Thyroid Res. 2011;152850: 1-9, http://dx.doi.org/10.4061/2011/152850.

37. Zhong J, You J, Gan Y, Zhang Y, Lu C. Job stress, burnout, depression symptoms, and physical health among Chinese university teachers. Psychol Rep. 2009;105(3):1-7.

38. Ravaglia G, Forti P, Maioli F, Pratelli L, Vettori C, Bastagli L, et al. Regular moderate intensity physical activity and blood concentrations of endogenous anabolic hormones and thyroid hormones in aging men. Mech Ageing Dev. 2001;122:191-203, http://dx.doi.org/10.1016/S00476374(00)00234-7.

39. Du H, Bennett D, Li L. Physical activity and sedentary leisure time and their associations with BMI, waist circumference, and percentage body fat in 0.5 million adults: The China Kadoorie Biobank study. Am J Clin Nutr. 2013;97(3):487-96, http://dx.doi.org/10.3945/ajcn.112.046854.

40. Naghii MR, Aref MA, Almadadi M, Hedayati M. Effect of regular physical activity on non-lipid (novel) cardiovascular risk factors. Int J Occup Med Environ Health. 2011;24(4):380-90, http://dx.doi.org/10.2478/s13382011-0044-9.

41. Edwardson CL, Gorely T, Davies MJ, Gray LJ, Khunti K, Wilmot EM, et al. Association of sedentary behaviour with metabolic syndrome: A Meta-Analysis. PLoS ONE. 2012;7(4):e34916, http://dx.doi.org/10.1371/journal. pone.0034916.

42. Bey L, Hamilton MT. Suppression of skeletal muscle lipoprotein lipase activity during physical inactivity: A molecular reason to maintain daily low-intensity activity. J Physiol. 2003;551(Pt 2):673-82, http://dx.doi.org/10.1113/jphysiol.2003.045591.

43. Liu Y, Chen L. New medical data and leadership on tobacco control in China. Lancet. 2011;377(9773):1218-20, http:/ dx.doi.org/10.1016/S0140-6736(10)61391-8.

44. Tang YL, Xiang XJ, Wang XY, Cubells JF, Babor TF, Hao W. Alcohol and alcohol-related harm in China: policy changes needed. Bull WHO. 2013;91:270-6, http://dx.doi. org/10.2471/BLT.12.107318.

This work is available in Open Access model and licensed under a Creative Commons Attribution-NonCommercial 3.0 Poland License - http://creativecommons.org/ licenses/by-nc/3.0/pl/deed.en. 